\title{
An overview of the Anguillid eel culture in Vietnam
}

\begin{abstract}
The wild eel fishery and eel farming are playing an increasingly important role in aquaculture. Most of the Anguillid eel fries at their glass eel stage are caught in the two provinces of Vietnam, viz., Phu Yen and Binh Dinh, which accounts for over $80 \%$ and 10$15 \%$, respectively. The stages of raising eels in Vietnam are very diverse with the survival rate of Anguilla Marmorata is approx. $60 \%$ through glass eel and elver stages. The major eel grow-out area of Vietnam is in Mekong delta. Ca Mau province is the highest in eel farming among the 14 provinces in the country. There are over 1,000 eel farms produced about 2,000-5,000 tons of eel in Vietnam at this moment. Around $95 \%$ of the total number of farms produced giant mottled eel (A. marmorata), and most of the production $(70 \%)$ was used for domestic consumption, while $30 \%$ was exported to the adjacent countries.
\end{abstract}

Keywords: anguillid eel, eel hatchery, eel farm, A. marmorata, A. bicolor, van xuan eel hatchery

\section{Introduction}

Vietnam is one of the four countries in which aquaculture production exceeded $(55.3 \%)$ fisheries production with $5.04 \%$ of global aquaculture production in 2018. ${ }^{1}$ The wild eel fishery, eel farming, and the import and export of eel products in Vietnam are quite diverse and play an increasingly important role in Southeast Asia and in the world. ${ }^{2}$

Study results have indicated that a total of 19 freshwater eel species/subspecies (16 species, 2sub-species and 1news species were discovered in 2009) are known to exist worldwide, especially in the Pacific, Atlantic, and Indian Oceans, and ofthese 19 eel species, 8 species/subspecies are known as the Southeast Asian Anguillid eels that inhabit the Southeast Asian waters, especially in the waters of Indonesia. ${ }^{3}$ Among the 8tropical Anguillid eels distributed in the Southeast Asia (Cambodia, Malaysia, Indonesia, Philippines, Thailand, Myanmar, and Vietnam), the most economically important species are the giant mottled eel (A. marmorata) and Indonesian short fin eel (A. bicolor). ${ }^{4}$

There are five species of Anguillid eel recorded in Vietnam, viz., A. nebulosi (McClelland, 1844), A. Japonica (Temminck and Schlegel, 1846), A. Marmorata (Quoy and Gaimard, 1824), A. Celebensis (Kaup, 1856), and A. bicolor pacifica (Schmidt, 1928). Conventional eel fishery must have been existed for a long time in Vietnam. However, the eel fishery for "collecting seeds towards eel farming" is rather new, started new, started in late 1990 then grew in the mid-late 2000s. In response to the development of eel farming industry in Vietnam, the target size of the eel fingerlings for culture became smaller, including yellow stage, elver stage, and glass eel stage. The main species for aquaculture in Vietnam are A. marmorata, while A. bicolor pacifica and A. japonica contribute under 5\%. As part of the study, data collection was done in the southern central provinces (where tropical Anguillid eel fisheries are practiced) by interviewing the eel consolidators, fishers, farmers and local officers (The survey was applied according to the method of Groves et al. ${ }^{5}$ as well as recording the statistics from country reports, and recently research results related to the situation of eel (Anguilla spp.) farming in Vietnam.

\section{Stages of anguillid eel farming in Vietnam}

There are several steps in the commodity chain of glass eel in Vietnam, especially on the process on elver and yellow eel stages. At
Volume 10 Issue 3 - 202I

\author{
Tuan Nguyen Thuc,' Duat Hoang Van² \\ 'Department of Aquaculture and Livestock Institute of \\ Agriculture and Natural Resources, Vinh University, Vietnam \\ ${ }^{2}$ Van Xuan eel hatchery, Aquaculture Research Institute No.3, \\ Vietnam
}
Correspondence: Nguyen Thuc Tuan, Department of Aquaculture and Livestock Institute of Agriculture and Natural Resources, Vinh University, Vietnam,
Email nguyenthuctuan@gmail.com

Received: May 24, 202I | Published: June 21, 2021 first, glass eel is collected by glass eel fishers. Eel collector receives glass eel from eel fishers. In some places (Phu Yen and Binh Dinh provinces), 2-3 steps for eel gathering systems are used via small eel collectors and large eel collectors. In some other areas, there is only one step of eel collector between glass eel fishers and hatcheries (breeding farms).

Hatcheries receive glass eel from eel collectors or middleman and rear them into elver and larger stages. After rearing glass eel to elver (and even larger) at the hatchery, various sizes of elver and yellow eel (1-100g/ind.) are sold to eel farms. Eel farmer rears these elver and yellow eel to certain size and then sell them to the other eel farmers. On anaverage, yellow eels as seeds are sold from an eel farm to another one at every 3-5 months. Such frequent trades of eel breeds are one of the measures to prevent the economic losses of eel farmers by reducing the risk of "Mass death" of the eel breeds caused by diseases and parasites in their farms. Finally, product size $(1-2 \mathrm{~kg} /$ ind.) are shipped to the market (Figure 1). In hatcheries, it takes 1218 months to rear glass eel to $100 \mathrm{~g}$ yellow eel. From $100 \mathrm{~g}$ to $1 \mathrm{~kg}$, it needs more 12-18 months. So, it takes 2.5-3 years from glass eel to $1 \mathrm{~kg}$ product size of $A$. marmorata in Vietnam.

\section{Exploiting natural fry resources and nursing of anguillid eels}

The source of elver eels for commercial farms in Vietnam comes through wild fishing, "breeding farms" from the glass eel to the elver eel stage, and imports from neighboring countries, such as China, Thailand, Cambodia etc. However, breed sources from "breeding farms", where glass eels are nursed to elver eel, play the most important role at present. Since the 2000s, the exploitation of wild eel fry resources in Vietnam mainly focus on catching eels at the glass eel stage or early elver eel stage to supply to the "breeding farms".

\section{Areas of fry exploitation}

The main glass eel fishing areas are located only in the central area of Vietnam. Majority of the glass eels are caught by the fishermen onlyat two provinces viz., Phu Yen and Binh Dinh, which account for over $80 \%$ and $10-15 \%$, respectively. Some other provinces also have natural sources of glass eel are Quang Ngai (about 2-5\%), Khanh Hoa (about 1\%), and Ninh Thuan (about 1\%). It seems likely that the fishermen could be able to collect eels throughout the year, depending on the area there is certain peak seasonality (Figure 2). 


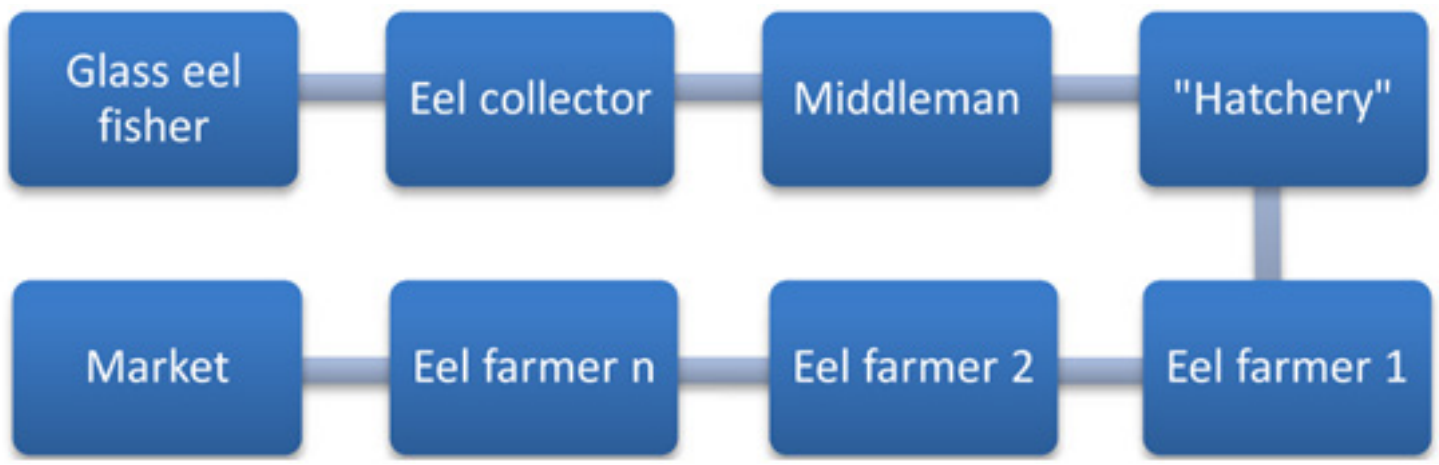

Figure I Schematic diagramof the commodity chain of glass eel in Vietnam.

Stages of eel production in Vietnam
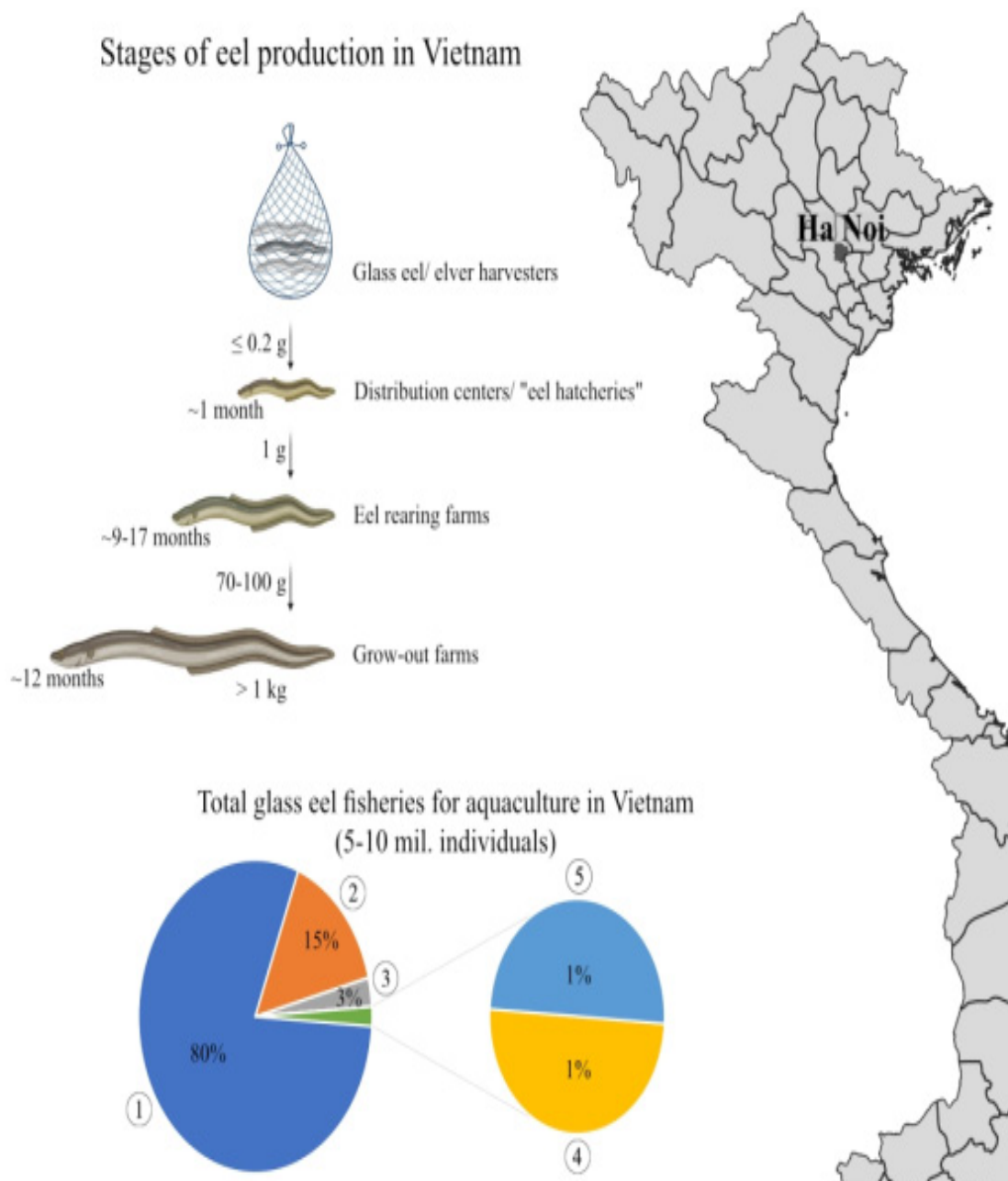

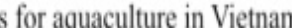
10 mil. individuals)

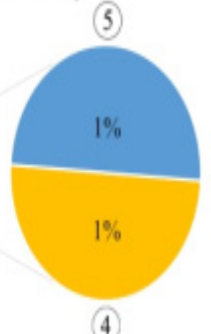

4

(SEAFDEC 2019)

Glass eels fishing areas (provinces)

(1) Phu Yen

(2) Bin Dinh

(3) Quang Nam

(4) Khanh Hoa

(5) Ninh Thuan

Provinces where aquaculture production occurs

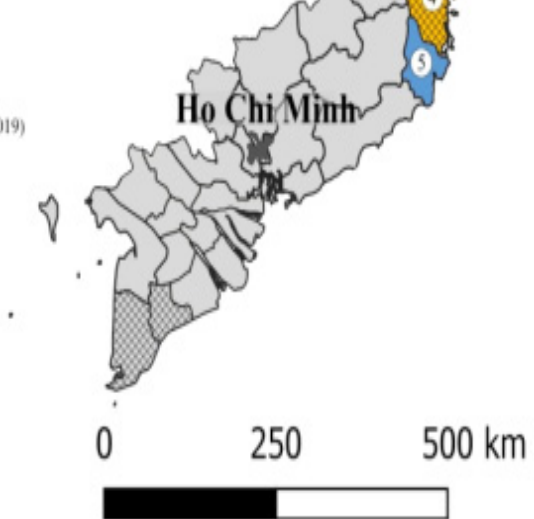

Figure 2 Eel aquaculture in Vietnam and main regions of eel harvesting and farming Panicz et al. ${ }^{8}$ 
The size of the early stage elver is almost similar tothat of glass eel and they are collected by scoop net and brush bundle trap together with glass eel. Since eel farmers (including hatcheries) prefer smaller and younger juvenile eel in recent years (for preventing disease infection before receiving by hatchery), the demand on glass eel becomehigherand that on elver become smaller.Glass eels and early elver eels $(\leq 0.2 \mathrm{~g})$ are caught and collected to supply to "eel breeding farms/eel hatcheries", nursed until reaching to a size of $1 \mathrm{~g} / \mathrm{ind}$., then transfer to eel rearing farms where they are reared up to $70-100 \mathrm{~g} / \mathrm{ind}$., and then continue to supply to Grown-out farms (Table 1).

Table I Stages and growth speed of A. marmorata at Van Xuan hatchery

\begin{tabular}{lllll}
\hline Stages (g/ind.) & $\leq \mathrm{I}$ & $\mathrm{I}-70$ & $70-100$ & $100-\geq 1000$ \\
Cultured time (month) & $\mathrm{I}-2$ & $8-9$ & $7-8$ & $1 \mathrm{I}-12$ \\
\hline
\end{tabular}

\section{Fishing gears}

Many types of fishing gears are used to catch small eels with 5 common types of fishing gears such as fyke net, fence net, scoop net, small seine net, and fish aggregating devices (FADs) (Table 2). The main methods of collecting glass eels are: 1) scoop net (at night), 2) fish aggregating devices (FADs) and 3) Fence net.

Table 2 Eel fishing gears in Vietnam

\section{Fishing gear}

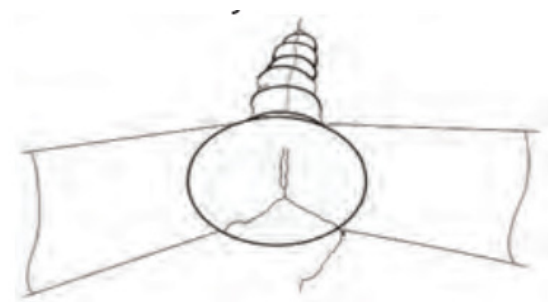

Fyke net

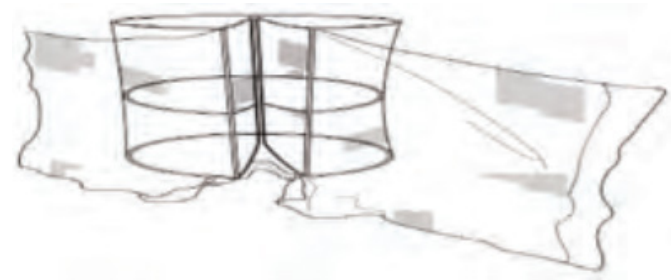

Fence net

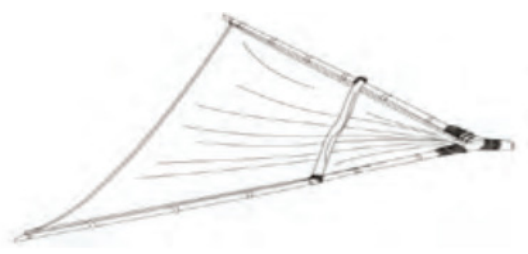

Scoop net

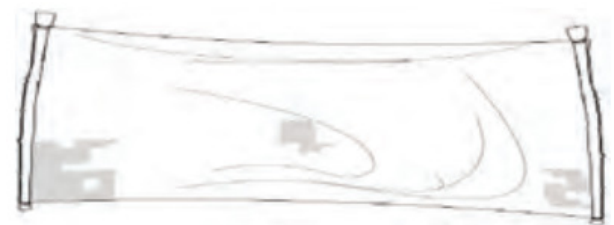

Small seine net

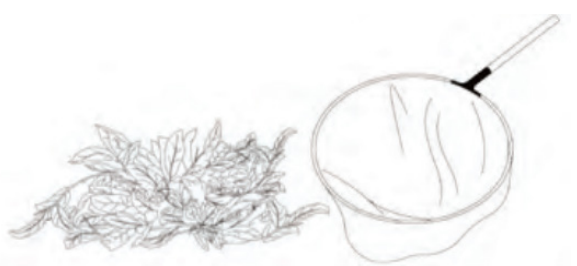

Fish aggregating devices (FADs)

\section{Structure and use}

* The frame is made of circled iron andcovered with small mesh-size net. The net is $6 \mathrm{~m}$ in diameter and $30 \mathrm{~m}$ inlength, and a $12 \mathrm{~m}$ wing is attached on eachside.

*The net is net in middle sides of rivers at 5 pmandhauled at 3 am.

* The frame is made of circled iron with adiameter of $50 \mathrm{~cm}$ and has a small mouth atthe center. The net has a wing of $1.5 \mathrm{~m}$ on each side. $*$ This net is set in rivers and operated from 5 pmuntill 0 pm

*The scoop net is made of wooden sticks andcovered with a small meshsize net.

* It is usually set in the mouth of rivers and downstream ofdams from 6 pmuntil 2 am.

* The net is made of two wooden sticks and a smallmesh-size net, and operated by two fishers.

* This type of seine net is usually set in the downstream of dams, from 6 pmuntil2 am.

\footnotetext{
* Fish aggregating devices (FADs)are madefrom branches of trees (Ky Lo River)and grasses (Ba River).

* Small scoop net is used to scoop the glasseels hiding under the FADs. * The FADs are set in the downstream of dams andoperated twotimes per day (from 3 pmuntil 5pm, andfrom 5 amuntil 8 am).
} 
Information on the fishing season for glass eels in Vietnam varies slightly between interviewees and fishing areas, but generally starts from October of the previous year to May of the following year.

\section{Breeding anguillid eels}

The most critical stage for eel aquaculture now in Vietnam is from glass eel to elver, of which the survival rate was recorded to be very low. To overcome this difficult process of eel farming in Vietnam, they established the special facilities called "eel hatchery" or "breeding farm". Hatchery does not mean the place for "hatching from the egg" in eel. It rears glass eel to elver and yellow eel as breeds for commercial farming.

There are many eel hatcheries in the South Middle of Vietnam. The main collected season for glass eel in Phu Yen province $(\geq 80 \%)$ is from October of previous year to May of next year, while it is from December of previous year to January of next year in Binh Dinh province (10-15\%), and other provinces as Quang Ngai (2-5\%), Ninh Thuan (1-2\%), Binh Thuan (1-2\%) (Figure 3). According to the expert interviews, total catch of glass eel as seeds for farming in Vietnam is about 5-10 million individuals per year.

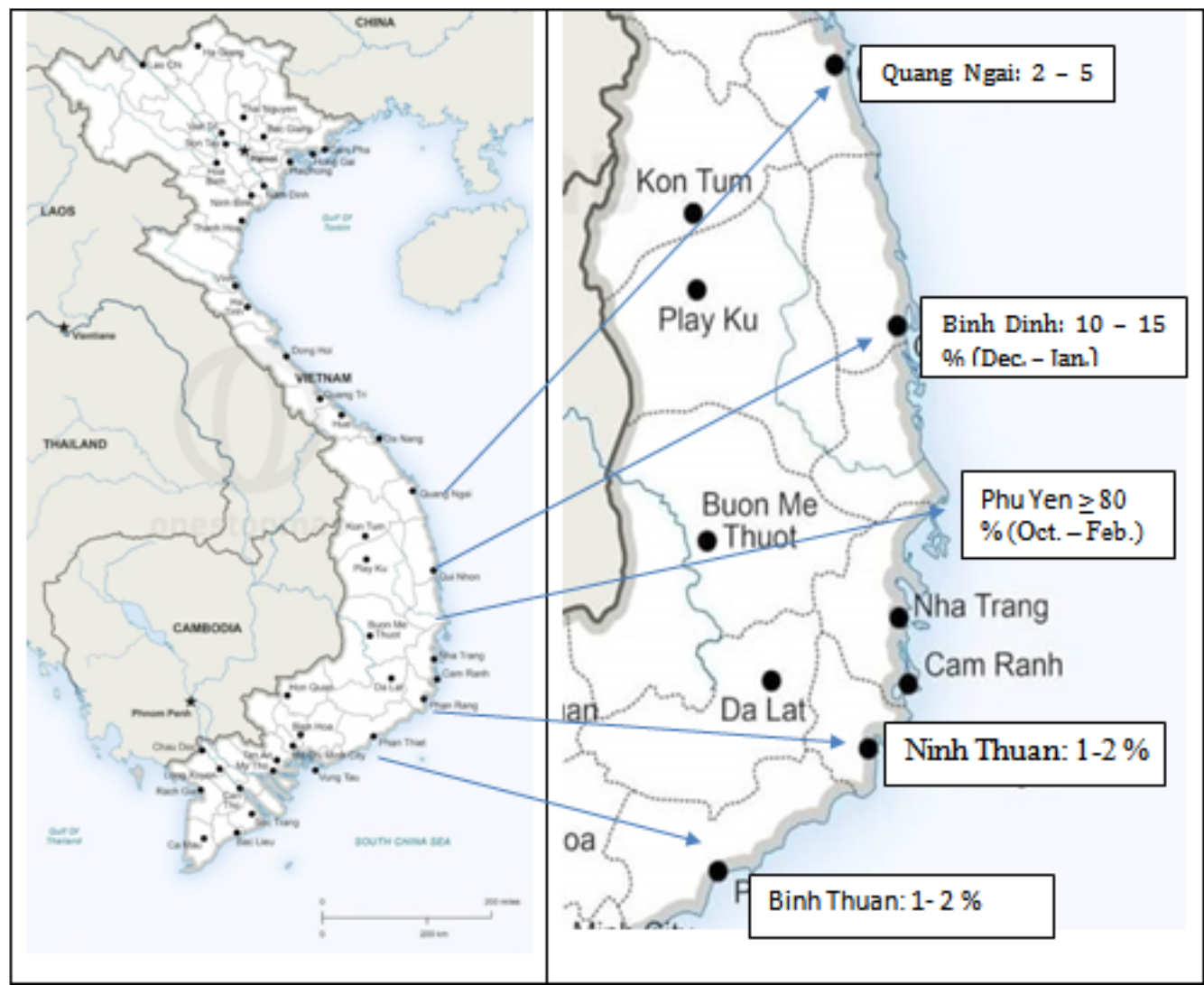

Figure 3 Sources of glass eels in Vietnam.

\section{Commercial eel farming and production in Vietnam}

Eel farmers exist in 37 provinces out of 64 provinces in Vietnam. There is no official record exactly how much eel farms exist in Vietnam. According to the interviews, there are 1,000 to 4,000 eel farms in Vietnam at the moment. The major eel grow-out area of Vietnam is in Mekong delta and Ca Mau province is the largest among the 14 provinces with eel farming at the moment. Many eel farms locate at Mekong delta area use trashed fish (such as tilapia) for rearing elver and yellow stage eels. Since there have been no catch statistics on eel (and the other freshwater fishes) in Vietnam, we do not know how much yellow eel and elver is caught every year. It seems that the main fishing efforts on eels in Vietnam has been shifting from yellow eel fishery into glass eel fishery, based on the decline of yellow eel catch and also the demands on glass eel from eel farms. The Da Rang River (the Bar River) in Phú Hòa district, is the biggest river in Phu Yen province and yellow eel fishery had been operated in this river by trap, angling and brush bundle trap. However, the amount of catch on yellow eel decreased year by years. Then fishers shift their target into glass eel. However, yellow eel fishery has also been conducted and some eel collectors treat yellow eel too.

In the anguillid eel farming, the growth stage of the eels is divided into some categories as follows: glass eel -> elver -> yellow eel -> silver eel. However in Vietnam, there are only two categories in the process of eel farming viz., glass eel (less than $0.2 \mathrm{~g} / \mathrm{ind}$.) and larger breeds (including elver and yellow eel) from $1 \mathrm{~g}$ to over $1 \mathrm{~kg} /$ ind. Instead of no classification between elver and yellow eel, eel farmers treat eel breeds based on their weight. It is needed to take care of the stages, especially on handling catch statistics of eels at stages.

There is no official statistics on the total production of eel farming in Vietnam, no one knows the accurate amount of eel production by eel farming in Vietnam. According to the interviews, we guess that $2,000-5,000$ tons of eel are produced by eel farming in Vietnam. In farms, it takes 2.5 years or more to rear glass eel (of $A$. marmorata) to 
the product size (more than $1 \mathrm{~kg} / \mathrm{ind}$ ). Especially at the early stages of eel farming process, the growth speed of anguillid eel varies with the conditions and hatcheries.

Survival rate of $A$. marmorata at each size category in hatcheries, rearing tank and/or eel farm varied with the conditions. The rearing condition in Van Xuan hatchery is the best in Vietnam and the total survival rate from glass eel to $50 \mathrm{~g}$ (yellow eel) is estimated as $56 \%$. In the other farms, the survival rate of $A$. marmorata is lower than that in Anguilla bicolorpacifica and many eel farmers struggle with the problem to increase the survival rate of $A$. marmorata. Considering these situations, approx. $60 \%$ survival rate of $A$. marmorata through glass eel and elver stages is quite excellent results.

\section{Market of anguillid eels in Vietnam}

According to SEAFDEC (2019) report, more than 1000 eel farms are distributed in the southern provinces of Vietnam, and $95 \%$ of the total number of farms produce giant mottled eel (A. marmorata), mostly $(70 \%)$ of which are used for domestic consumption (in the restaurant as Vietnamese Anguillid eel soup, deep fried, fried with curry, steam, etc.). Remaining $30 \%$ of the production is exported to the adjacent countries (e.g., Taiwan, China and Japan) in which fish market with expensive Japanese eel (A. japonica) is supplemented with more affordable giant mottled eel. ${ }^{1,6}$ Figure 4 shows the share of the live eels import (in value) by four importing countries, namely Cambodia, Malaysia, Thailand, and Vietnam. A big bulk (89\%) of the total live eels imported by the Southeast Asian region was made by Vietnam, while (7\%) was made by Cambodia which mainly came from the Philippines. ${ }^{7}$

\section{Import Value for Live Eels in 2016}

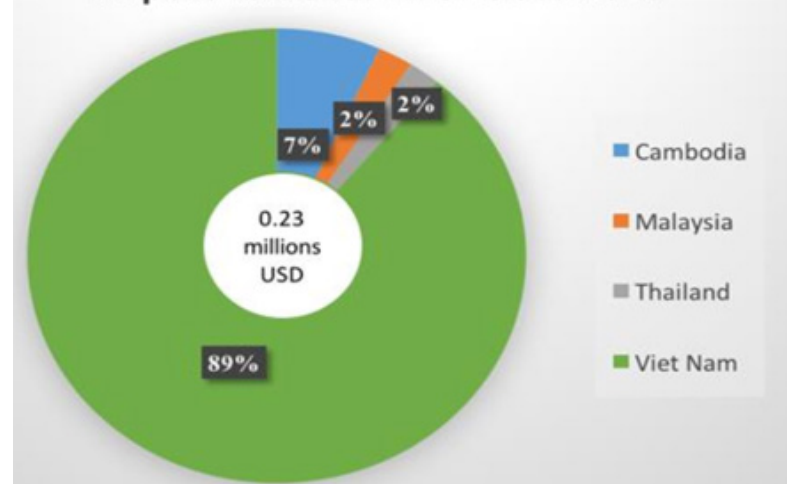

Figure 4 Shares of live eels import value by four Southeast Asian countries in 2016.

The price of the eel breeds varies with the market demands. The following Table 3 just represents the tentative information. To record the situation in January 2017, we list up the prices of eel at each size/ stage.

Table 3 Price of eel (A. Marmorata) seeds in Van Xuan eel hatchery at each sizein 2017

\begin{tabular}{llll}
\hline Sizes (g/ind.) & $\leq 0.2$ & 70 & 100 \\
Prices (USD) & $0.1-0.2$ & $3-3,5$ & $5-7$ \\
\hline
\end{tabular}

At present, Van Xuan company is reaching to tranfer eel farming techlonogy as well as supplying quality eel seeds to other areas of Middle and Northern areas. Van Xuan eel hatchery in Nha Trang, is the largest and most advanced eel hatchery in Vietnam, with the technical support from Research Institute of Aquaculture No.3.
Approximately 500thousand to 1 million individuals of glass eel are received every year.

\section{Difficulties and conservation measures on eels in Vietnam}

There is no special conservation measure on anguillid eels in Vietnam as of now. National government chose Song Hinh Reservoir in Phu Yen province as the eel conservation area in $2008 .{ }^{8}$ However, there has not been any actual activities conducted yet, because of the budget shortage. Import and export of wild eel are prohibited by law (except exporting the aquaculture products from Vietnam to the other countries).

Eel farms in Vietnam are facing a lot of difficulties such as: the source of fry is not stable because $100 \%$ of it's catch is done from wild, expensive (average 20\$/kg), long-term culture (at least 15 months), poor farming technology, many disease pathogens (parasite, viruses, bacteria etc.), and artificial feed with high price.

\section{Conclusions}

The stages of raising eels in Vietnam are very diverse. Conventional farms include the following stages: glass eel $-1 \mathrm{~g} /$ ind. (1-3 month), $1-70 \mathrm{~g} /$ ind. (8-9 month), 70-100g/ind. (8-9 month), 100- $\geq 1000 \mathrm{~g} /$ ind. (12 month). The survival rate of $A$. marmorata is lower than $A$. bicolor. The survival rate of $A$. Marmorata is approx. $60 \%$ through glass eel and elver stages.

Majority of the glass eels are caught at the two provinces of Vietnam, viz., Phu Yen and Binh Dinh, which accounts for over $80 \%$ and $10-15 \%$ of total catch, respectively, by many types of fishing gears such as Fyke net, Fence net, Scoop net, Small seine net, and fish aggregating devices (FADs). Some other provinces also have natural sources of glass eel including Quang Ngai (about 2-5\%), Khanh Hoa (about 1\%), and Ninh Thuan (about 1\%). Total catch of glass eel as breeds for farming in Vietnam is about 5-10 million individuals per year including $A$. marmorata (94-95\%) and A. bicolor (4-5\%).There is no special conservation measure on anguillid eels in Vietnam as of now.

The major eel grow-out area of Vietnam is in Mekong delta. Ca Mau province is the largest among the 14 provinces with eel farming. There are over 1,000 eel farms produced about 2,000-5,000 tons of eels in Vietnam in which most of the production $(70 \%)$ is used for domestic consumption, while $30 \%$ is exported to adjacent countries.

\section{Funding}

This research project was partially sponsored by the Minister Education and Training of Vietnam with the grant number B2019TDV-05.

\section{Acknowledgments}

The authors greatly acknowledge are much indebted to the fishermen, farmers, researchers, and local officers in provinces in the Middle of Vietnam as Quang Ngai, Binh Dinh, Phu Yen, Khanh Hoa, Binh Thuan, and Ninh Thuan provinces in Vietnam, and especially Van Xuan eel farm (Cam Lam district, Khanh Hoa province), supported in this study for their many helps and cooperation during this study.

\section{Conflicts of interest}

The author declares that there are no conflicts of interest. 


\section{References}

1. Ni Komang Suryati, Yanu Prasetiyo Pamungkas, Dina Muthmainnah, et al. Addressing the Issues and Concerns on Anguillid EelFisheries in Southeast Asia. Fish for the People, Southeast Asian Fisheries Development Center, Bangkok, Thailand. 2019;17(1):19-25.

2. SEAFDEC. Status and Resources Management of Tropical Anguillid Eels in Southeast Asia, AC30 Inf. 11, Thirtieth meeting of the Animals Committee Geneva (Switzerland). 2018.

3. Arai T, Aoyama J, Limbong D, et al. Species composition and in shore migration of the tropical eels Anguilla spp. recruiting to the estuary of the Poigar River, Sulawesi Island. Mar Ecol Prog Ser. 1999;188:299-303.

4. Crook V, Nakamura M. Glass eels: Assessing supply chain and market impacts of a CITES listing on Anguilla species. Traffic Bulletin. $2013 ; 25(1): 24-30$.
5. Honda S, Muthmainnah D, Suryati NK, et al. Exchanging Information on Catadromous Eels in South east Asia. SEAFDEC-Newsletter. 2016; 39(2).

6. Groves RM, Fowler FJ, Couper MP, et al. Survey Methodology. Hoboken, NJ: Wiley. 2004.

7. Muthmainnah D, Honda S, Suryati NK, et al. Understanding the Current Status of Anguillid Eel Fisheries in Southeast Asia. In: Fish for the People, Southeast Asian Fisheries Development Center, Bangkok, Thailand. 2016;14(3):19-25.

8. Remigiusz Panicz, Piotr Eljasik, Tuan Thuc Nguyen, et al, First detection of Herpesvirus anguillae (AngHV-1) associated with mortalities in farmed giant mottled eel (Anguilla marmorata) in Vietnam. Journal of Fish Diseases. 2021;44(6 )847-852. 